\title{
Assessment of Static Electrical Propensity for Work Clothes Using Human Body Voltage Measuring Methods
}

\author{
Kimura Hirokazu *, Yamamoto Ryotaro, SAKaguchi Akio \\ Faculty of Textile Science and Technology, Shinshu University, Ueda, Nagano 386-8567, Japan
}

Received 9 April 2018; accepted for publication 5 July 2018

\begin{abstract}
Safety quality on the static electrical propensity of work clothes in Japan is confirmed by electrical resistivity or frictional electric charge obtained from the results of test methods specified by International Electrotechnical Commission standard (IEC) or Japanese Industrial Standard (JIS). In practical use, we consider that the hazard related to static electrical charge is dependent on human body voltage caused by various movement of worker during working hours as well as electrical resistance or electric charge amount of work clothes. We thought up two trial movements for determination of human body voltage: one is taking off movement after performing frictional action between work clothes and inner wear during 20 seconds at speed of 90 times per one second, and the other is standing up from the seat of popular use chair quickly after performing frictional action between the back part of work clothes and the back of a chair during 60 seconds at speed of 90 times per one second. Experimental works were performed by using four types of unprotected commercial work clothes and six types of static protected commercial work clothes. As the experimental results, standing up movements from the seat of chair were recorded higher human body voltages than taking off movement. From the almost all work clothes including static protected work clothes, the human body voltage above 3000 voltage which many human felt static electrical shock were detected by the standing up from the chair quickly after performing frictional action.
\end{abstract}

Key Words : Static electrical propensity, Human body voltage, Work clothes, Safety quality of static electrical propensity

\author{
人体帯電圧による作業服の静電気带電性評価 \\ 木村裕和 *, 山本涼太郎, 坂口明男 \\ 信州大学繊維学部
}

\section{1. 緒 言}

静電気帯電現象が様々な障害や災害を引き起こすことは周 知のとおりである $[1,2]$. 静電気帯電を原因とするトラブル には，静電気引力による埃の付着や日常的に経験する静電気 放電時に受ける痛み，不快感，冬季の乾燥期に発生する脱衣 時の静電気放電音など比較的軽微なものから静電気帯電を原 因とする爆発や火災事故のように極めて深刻な事例に至るま で実に多くの事象が報告されている [3-6]. 今から 10 年以上 前のことになるが, 製油所の原油貯蔵タンクで静電気带電が 原因と考えられる火災が発生し，7名の作業員のうち5名が
死亡, 2 名が軽傷を負う大事故となった [7]. 当時の新聞報 道から作業員は静電気帯電防止作業服を着用していたものと 推測される [7].

日本工業規格では JIS T 8118 に静電気帯電防止作業服の規 格值とその試験方法が規定されている $[8]$. JIS では作業服の 静電気的安全性を確認するために作業服生地と作業服一式を 試料として摩擦帯電電荷量を求める方法が定められており, 前者が $7 \mu \mathrm{C} / \mathrm{m}^{2}$ 以下, 後者が作業服上下一式で $0.6 \mu \mathrm{C} /$ 点でな ければならないと規定されている。また, 国際電気標準会 議では IEC 規格, IEC 61340-5-1 に電気抵抗值による規格值 が規定されており，作業服生地の電気抵抗值が $1.2 \times 10^{12} \Omega$

* 連絡先 : 信州大学繊維学部 386-8567 長野県上田市常田 3-15-1

E-mail : hiro@shinshu-u.ac.jp, Tel : +81-268-21-5362 
以下であることが要求されている $[9]$. しかしながら静電気 帯電防止作業服を着用して作業していたにもかかわらず，静 電気が原因と疑われる不幸な事故は現実に発生した。

著者らは作業服着用時の動作や着脱衣時に人体に生じる静 電気带電量を知ることが極めて重要であると考えている。

そこで，人体帯電圧による作業服の静電気带電性評価の可 能性を探索する目的ならびに市販の作業服から実際にどの程 度の人体帯電圧が生じるのかを確認する目的から 2 通りの試 技を考案した。1つの試技は作業服を着用した実験者が静止 起立状態で作業服とインナーウエアを一定の速度で一定時間 摩擦し，素早く脱衣する所作で，脱衣動作試技である。もう 1 つは，汎用的な事務椅子に作業服を着用した実験者が深く 座り，作業服背部と椅子の背もたれ部分を一定角度で一定の 速度, 一定の時間摩擦し, 直ちに立ち上がる動作で, 椅子か らの立ち上がり動作試技である。この 2 種類の試技から得ら れた実験結果を報告する。

\section{2. 実験}

\section{1 試料作業服}

実験に用いた試料作業服は上下一対の市販の作業服であ る、いずれも一般的な作業服である. Table 1 に試料作業服 の带電防止加工の有無と春夏用, 秋冬用の別, 試料作業服 の素材, 厚さおよび重量を記載した。帯電防止未加工作業 服は試料作業服 No.1 から試料作業服 No.4 の 4 点で, 春夏 用 2 点, 秋冬用 2 点である。素材はポリエステル $65 \%$, 綿 $35 \%$ およびポリエステル $100 \%$ がそれぞれ 2 点である。試料 作業服 No.5 から試料作業服 No.8 の 4 点が JIS 規格適合作業 服で，春夏用と秋冬用がそれぞれ 2 点である。素材はポリ エステル $65 \%$, 綿 35\% およびポリエステル $100 \%$ がそれぞ れ 2 点である。試料作業服 No.9 および試料作業服 No.10 が IEC 規格適合作業服で, 春夏用, 秋冬用が各 1 点, 素材はポ
リエステル $100 \%$ である。なお，試料作業服の厚さは背中部 分の生地厚さを Thickness Gauge (大栄科学精器製作所社製 Fs-60DS）により求め, 試料作業服の重量は秤（OHAUS 社 製 NAVIGATOR XL）を用いて計測した。

脱衣動作試技および椅子からの立ち上がり動作試技ともに インナーウエアには一般的な綿 100\%の長袖 T シャツを選定 した。

\section{2 表面電気抵抗測定}

実験に用いた 10 種類の試料作業服の表面電気抵抗率を高 抵抗計（三菱化学アナリテック社製ハイレスターUX）を用 いて測定した。印加電圧は $1000 \mathrm{~V}$ とし, 電圧印加後 300 秒経 過後の電気抵抗率を測定した。たたし，試料作業服 No.9お よび試料作業服 No.10については印加電圧を $50 \mathrm{~V}$ とした。な お，測定は温湿度環境を $20 \pm 2^{\circ} \mathrm{C} ，(20 \pm 2 ） \% R . H$. に調整した 恒温恒湿実験室内で行った。

\section{3 着衣動作試技}

実験は温湿度環境を $20 \pm 2{ }^{\circ} \mathrm{C} ，(20 \pm 2 ） \% R . H$. に調整した恒 温恒湿実験室内で行った。予備実験の結果から履物裏面から の電荷の漏えいを防ぐため, 床面には JIS L 1021-16.6.1.4に 規定の絶縁版の上に生産方向に対して平行に $300 \mathrm{~mm}$, 直角 に $300 \mathrm{~mm}$ の大きさのウール $100 \%$ のウィルトンカーペット を重ね敷いた床材の上で次の手順で試技を実施した。

最初に試料作業服上下一対を着用した実験者が人体帯電圧 測定器（日本スタテック社製 SV-82A）に接続されているプ ローブを作業ズボンのポケットに入れ，恒温恒湿実験室内の 床面に設置した床材上に起立状態で静止する（Fig.1 a)。そ の後, 試料作業服を脱ぐ動作を行う。 その際, 試料作業服と インナーウエア間を速さ 90 回/min. で 20 秒間摩擦運動を行っ た (Fig.1 b). 所定時間の摩擦運動が終了後, 素早く試料作

Table 1 Details of work clothe used as experimental sample.

\begin{tabular}{|c|c|c|c|c|c|}
\hline Sample No. & Unprotected or static protected & For season & Material(s) & Thickness (mm) & Weight (gf) \\
\hline 1 & Unprotected & Spring and summer & Polyester $65 \%$, Cotton $35 \%$ & 0.47 & 707.0 \\
\hline 2 & Unprotected & Autumn and winter & Polyester $65 \%$, Cotton $35 \%$ & 0.68 & 978.4 \\
\hline 3 & Unprotected & Spring and summer & Polyester $100 \%$ & 0.41 & 647.8 \\
\hline 4 & Unprotected & Autumn and winter & Polyester $100 \%$ & 0.74 & 945.9 \\
\hline 5 & Static protected specified by JIS & Spring and summer & Polyester $65 \%$, Cotton $35 \%$ & 0.44 & 641.5 \\
\hline 6 & Static protected specified by JIS & Autumn and winter & Polyester $65 \%$, Cotton $35 \%$ & 0.66 & 1059.3 \\
\hline 7 & Static protected specified by JIS & Spring and summer & Polyester $100 \%$ & 0.29 & 582.0 \\
\hline 8 & Static protected specified by JIS & Autumn and winter & Polyester $100 \%$ & 0.59 & 1178.5 \\
\hline 9 & Static protected specified by IEC & Spring and summer & Polyester $100 \%$ & 0.35 & 625.9 \\
\hline 10 & Static protected specified by IEC & Autumn and winter & Polyester $100 \%$ & 0.62 & 893.7 \\
\hline
\end{tabular}



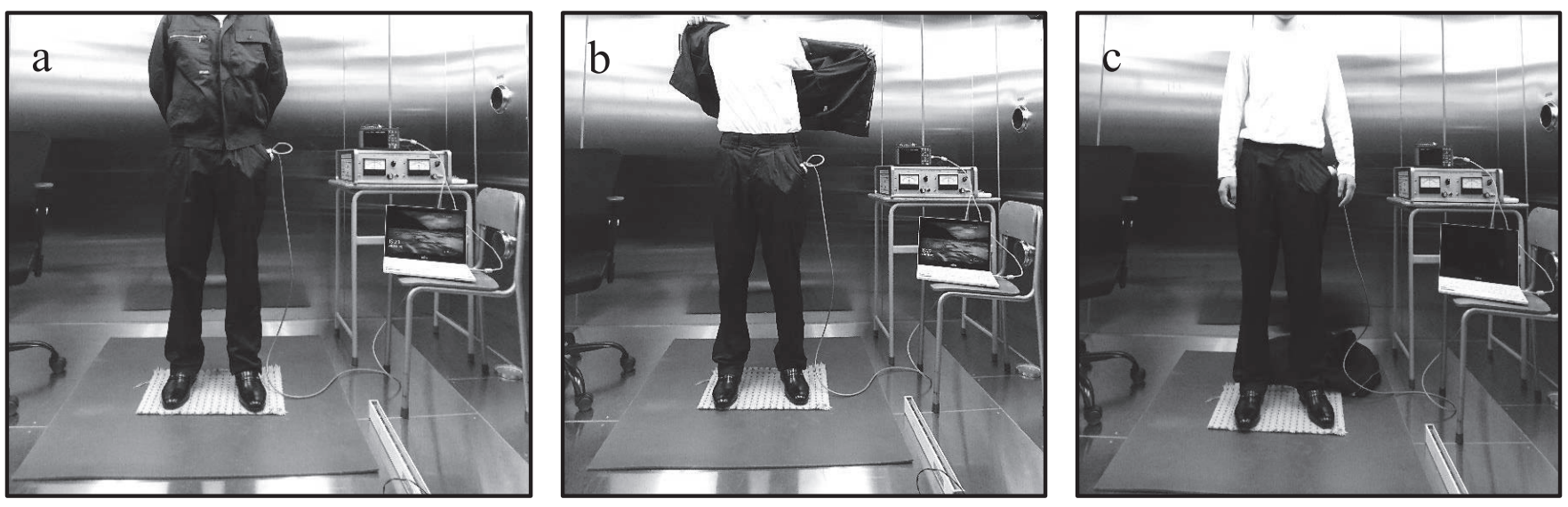

Fig. 1 Photographs of taking off test method after performing frictional action between work clothes and inner wear.

業服を脱衣し，床面に放置する動作を行った（Fig.1 c)，実 験は 1 試料作業服につき 3 回行い,メモリーハイロガー（日 置電機社製 LR8431）に記録された人体帯電圧の最大值を測 定データとして採用し，その平均值を求めた。な押，実験終

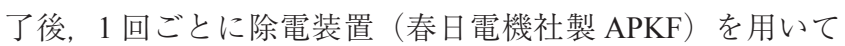
試料作業服上下一対捛よびインナーウエアを入念に除電し た.

\section{4 椅子からの立ち上がり動作試技}

実験は 2-3に記述した恒温恒湿実験室内で行い, 装置, 器具, 道具は2-3 と同じものを用いた。

試技は，次の手順で実施した，Fig. 2 に示したように試料 作業服の上下一対を着用した実験者が人体帯電圧測定器に接 続されているプローブを握り，静かに市販の汎用椅子(ニト リ社製ワークチェアベリー2BK）に深く座る。この椅子の座 面㧍よび背もたれ部はポリエステル $100 \%$ の織物生地で構成 されている。 その後, 椅子の背もたれ部を試料作業服の背中 部で実験者の座骨結節部を中心に左右約 $20^{\circ}$ の角度となるよ

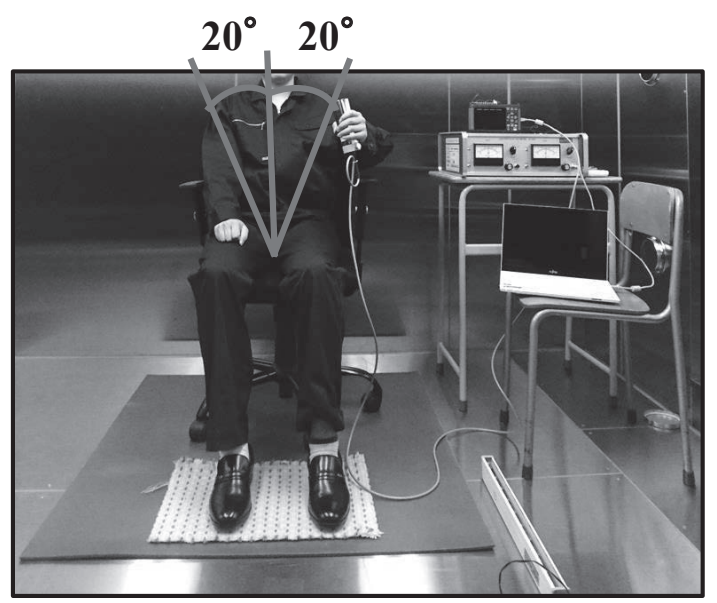

Fig. 2 A photograph of standing up test method from the seat of chair quickly after performing frictional action between back part of work clothes and back of a chair.
うに速さ 90 回 $/ \mathrm{min}$. で 60 秒間往復摩擦運動を行った。所定 時間の摩擦運動が終了後，素早く椅子から立ち上がる動作を 行った。実験は 1 試料作業服につき 3 回行い, 立ち上がり直 後にメモリーハイロガーに記録された人体帯電圧の最大值を 測定データとし, その平均值を求めた。な抄, 実験終了後, 1 回ごとに除電装置を用いて試料作業服上下一対抢よび椅子 の背もたれ部ならびに座面を入念に除電した。

な掞，着衣動作試技掞よび椅子からの立ち上がり動作試技 ともに標準的体格（身長 $172 \mathrm{~cm}$, 体重 $65 \mathrm{kgf}$ ) の成人男性 1 名が実施した。

\section{3. 結果と考察}

Fig.3には脱衣動作試技から得られた人体带電圧のチャー トの一例を，Fig.4には椅子からの立ち上がり動作試技から 得られた人体帯電圧のチャートの一例を示した. Fig. 3 に示 した脱衣動作試技に扔いては試料作業服とインナーウエア間 で摩擦を行っている 20 秒間に人体帯電圧は $1.5 \mathrm{kV}$ 程度に上 昇している。 そして, 試料作業服を脱いだ瞬間に急激な上昇

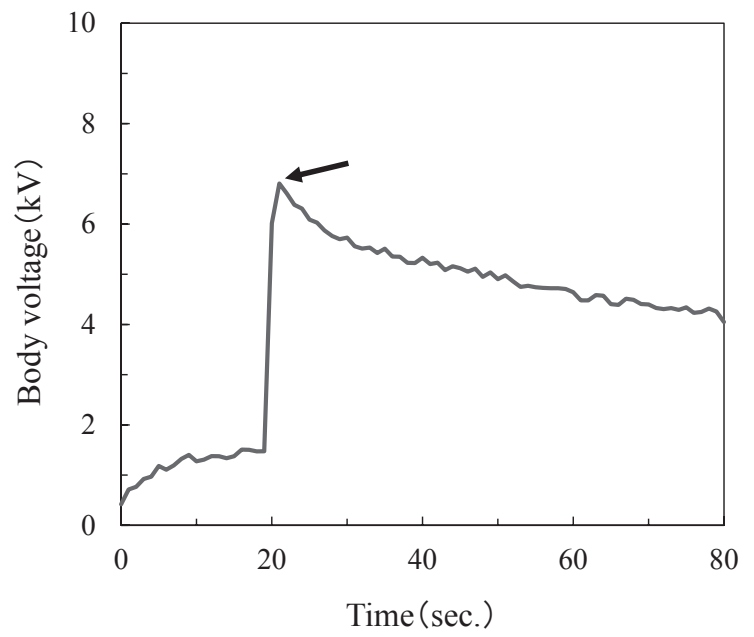

Fig. 3 Body voltage curve obtained from taking off test method after performing frictional motion. 


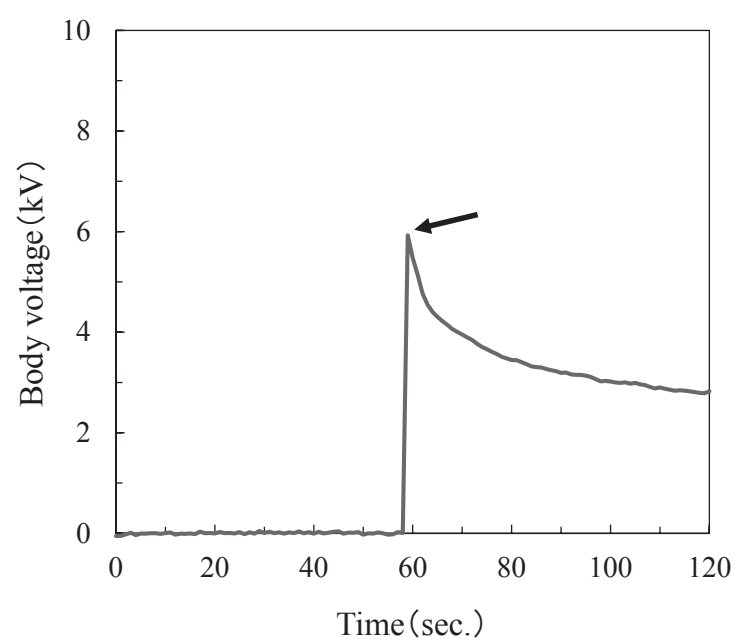

Fig. 4 Body voltage curve obtained from standing up test method from the seat of chair quickly after performing frictional motion.

が認められ，数秒間で $7 \mathrm{kV}$ 弱にまで達している。その後, 60 秒間の静止起立状態時において人体帯電圧の減衰が認めら れ， 60 秒後にはおよそ $4 \mathrm{kV}$ を示していることがわかる.

一方, Fig.4に示した椅子からの立ち上がり動作試技にお いては椅子の背もたれ部と試料の背中部との間で摩擦運動を 行っているときには, 静電気帯電はほとんど生じていない. しかし, 立ち上がり動作を行うと同時に人体帯電圧は急激に 上昇し， $6 \mathrm{kV}$ 程度の帯電圧が検出されている。 その後, 60 秒 間の静止起立状態において帯電圧の減衰が認められる。この 例では Fig.3の減衰速度よりも早く, 60 秒後には半減してい る.

なお, 脱衣動作試技および椅子からの立ち上がり動作試技
ともに Fig.3 および Fig.4 に矢印で示した人体帯電圧の最大值 をデータとして採取した。

ここで, Table 2 に示した試料の表面電気抵抗率測定の結 果に注目する. IEC 規格適合作業服である試料作業服 No.9 および試料作業服 No.10 の電気抵抗率は $10^{7}$ のオーダーであ る。帯電防止未加工作業服抢よびJIS 規格適合作業服に比べ, $10^{6}$ から $10^{9}$ 低い值である。これは先述したようにIEC 規格 では作業服の静電気的安全性を表面電気抵抗で管理している

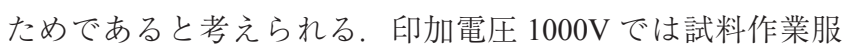
No.9 および試料作業服 No.10 は Under range の表示となり,

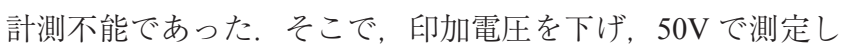
た。一方, 带電防止未加工作業服の表面電気抵抗率は $10^{13}$ か ら $10^{16}$ のオーダーを示し, JIS 規格適合作業服は $10^{13}$ または $10^{14}$ のオーダーである。したがって，JIS 規格適合作業服の 電気抵抗值自体はそれほど低いものではないことがわかる。

仮に人体帯電現象が単純に試料作業服の電気抵抗のみに依 存するのであれば，脱衣動作試技および椅子からの立ち上が り動作試技においては検出される人体帯電圧は, IEC 規格適 合作業服《JIS 規格適合作業服带電防止未加工作業服とな るはずである. Fig.5には, よこ軸に表面電気抵抗率, たて 軸に脱衣動作試技から得られた人体帯電圧および椅子からの 立ち上がり動作試技から得られた人体帯電圧のデータを示し た。○で示した脱衣動作試技においては IEC 規格適合作業服 である試料作業服 No.9 および試料作業服 No. 10 の人体帯電 圧は, $-0.6 \mathrm{kV}$ および $-0.5 \mathrm{kv}$ と小さく, 電気抵抗率が低い試料 作業服の人体帯電圧が低いことがわかる。 しかし, 電気抵抗 率が $10^{13}$ から $10^{16}$ のオーダーの試料群からは電気抵抗率と人 体帯電圧との間に関連性は認められない。一方, ○で示した 立ち上がり動作試技では IEC 規格適合作業服を含め, すべて の試料作業服において表面電気抵抗率が低いほど人体帯電圧

Table 2 Body voltage and electrical resistance obtained from taking off test method after performing frictional action between work clothes and inner wear and standing up test method from the seat of chair quickly after performing frictional motion.

\begin{tabular}{cccc}
\hline Sample & $\begin{array}{c}\text { Body voltage obtained from } \\
\text { taking off test method }(\mathrm{kV})\end{array}$ & $\begin{array}{l}\text { Body voltage obtained from } \\
\text { standing up test method } \\
\text { from the seat of chair }(\mathrm{kV})\end{array}$ & Electrical resistance $(\Omega /$ 口) \\
\hline 1 & -6.8 & 8.1 & $5.9 \times 10^{13}$ \\
\hline 2 & -8.1 & 9.0 & $1.6 \times 10^{13}$ \\
\hline 3 & 4.0 & 3.1 & $5.8 \times 10^{15}$ \\
\hline 4 & 8.0 & -5.7 & $1.4 \times 10^{16}$ \\
\hline 5 & 0.8 & 3.9 & $9.7 \times 10^{13}$ \\
\hline 6 & 0.9 & -0.9 & $5.7 \times 10^{13}$ \\
\hline 7 & -2.5 & 5.2 & $8.3 \times 10^{14}$ \\
\hline 8 & -2.1 & 6.0 & $4.7 \times 10^{14}$ \\
\hline 9 & -0.6 & 6.0 & $3.5 \times 10^{7}$ \\
\hline 10 & -0.5 & 6.9 & $4.0 \times 10^{7}$ \\
\hline
\end{tabular}




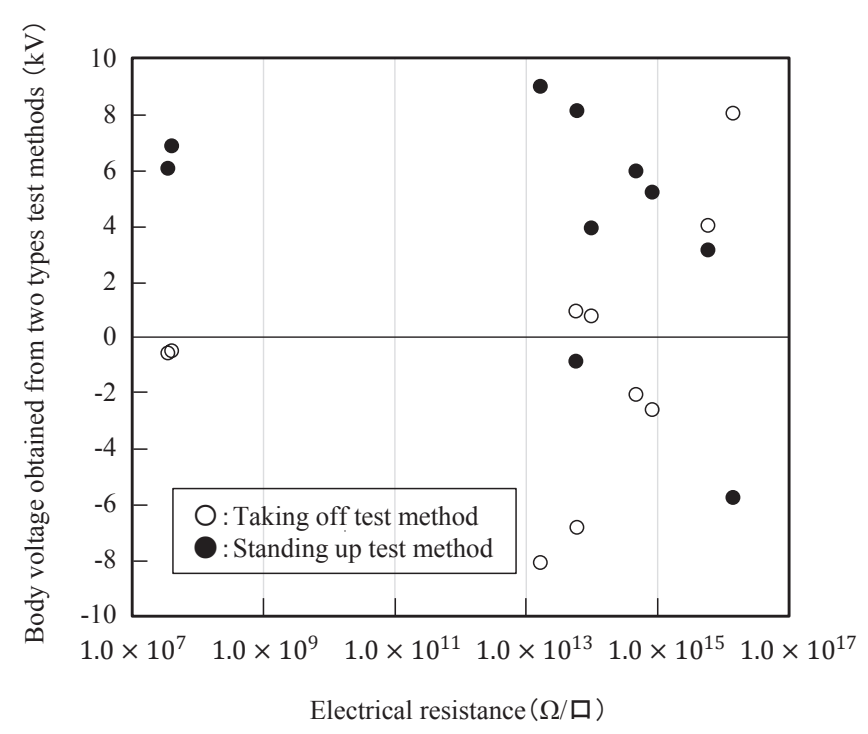

Fig. 5 Relationship between electrical resistance and body voltage obtained from taking off test method after performing frictional motion $(O)$ and standing up test method from the seat of chair quickly after performing frictional motion

が小さくなるという傾向は認められない.この結果は, 床材 試料の電気抵抗值と歩行動作により生じる人体帯電圧との関 係を検討した先行研究の結果と類似している [10]. したがっ て, 実際の作業時に人体に発生する静電気帯電量を電気抵抗 の測定結果からだけで推測することは困難であるといえる.

次に, Table 2 に示した脱衣動作試技の結果に注目する. 帯電防止加工作業服である試料作業服 No.5 から試料作業服 No.10の 6 点の試料作業服から検出された人体帯電圧の平均 值は絶対值で $0.5 \mathrm{kV}$ から $2.5 \mathrm{kV}$ の範囲にある. 帯電防止未加 工作業服である試料作業服 No.1 から試料作業服 No.4 の 4 点 の試料作業服から得られた人体帯電圧の絶対值は $4.0 \mathrm{kV}$ から $8.1 \mathrm{kV}$ の範囲である。人体帯電圧の絶対值が $3 \mathrm{kV}$ を超過する と静電気放電ショックを感じ, $5 \mathrm{kV}$ 以上で放電火花が生じる ことはよく知られた事実である [11]. 脱衣動作試技において は，すべての帯電防止未加工作業服が静電気放電ショックを 感じるレベルにある。一方, JIS 規格適合作業服および IEC 規格適合作業服の 6 点の試料作業服においては, そのすべて が $3 \mathrm{kV}$ 未満の带電圧である. 静電気放電ショックを感じるレ ベルではないことがわかる. したがって, 帯電防止加工作業 服は脱衣のような通常, 普通に行う動作であれば, 静電気的 な危険性は低く, 制電加工効果は認められるものといえる.

一方，椅子からの立ち上がり動作試技から得られたデー夕 をみると帯電防止未加工作業服である試料作業服 No.1 から 試料作業服 No.4の人体帯電圧の絶対值は $3.1 \mathrm{kV}$ から $9.0 \mathrm{kV}$ の範囲である. JIS 規格適合作業服である試料作業服 No. 5 か ら試料作業服 No.8の人体帯電圧の絶対值は $0.9 \mathrm{kV}$ から $6.0 \mathrm{kV}$ の範囲であり, IEC 規格適合作業服の試料作業服 No.9 およ び試料作業服 No.10の人体帯電圧は, それぞれ $6.0 \mathrm{kV}, 6.9 \mathrm{kV}$ である．全体的に脱衣動作試技に比べて椅子からの立ち上が り動作試技の方が高い人体帯電圧を示している. 帯電防止加

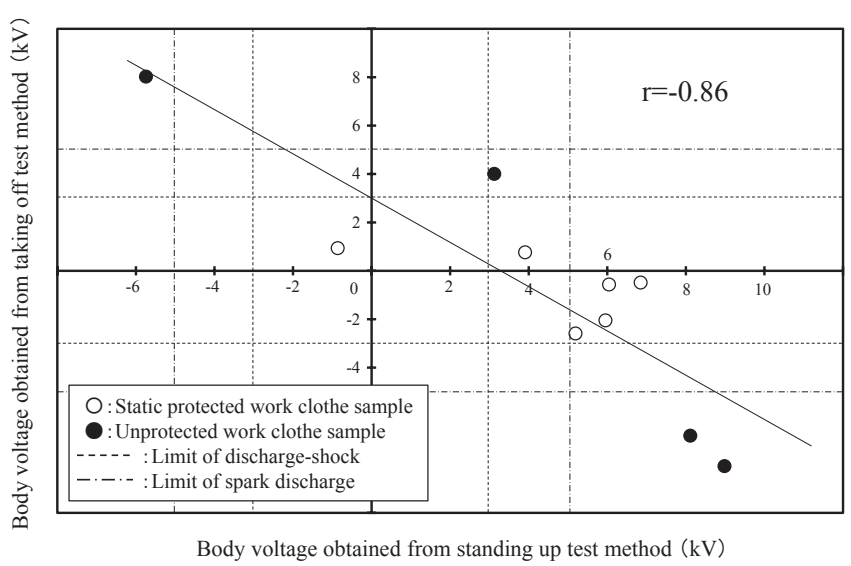

Fig. 6 Relationship between body voltages obtained from taking off test method after performing frictional motion and standing up test method from the seat of chair quickly after performing frictional motion.

工作業服 6 点中 5 点が $3 \mathrm{kV}$ を超過しており, そのうちの 4 点 が $5 \mathrm{kV}$ を超過している. 実に, 帯電防止作業服の $2 / 3$ が静電 気による火花放電の危険性がある。したがって, 带電防止作 業服を着用していても激しい摩擦をともなうような動作や作 業の後に, 急速に立ち上がるような動作は危険をともなう所 作であることが実験的に示されたものと考えている．

なお，脱衣動作試技においては低い帯電圧を示した IEC 規 格適合作業服でも立ち上がり動作試技ではかなり高い人体帯 電圧が検出されている。これは, 試料作業服生地の電気抵抗 が低いために椅子の背もたれ部分と作業服の背中部を促進的 に摩擦した後に直ちに素早く立ち上がるというダイナミック な動作にともなってはく離時に急激な電荷の移動が大面積で 発生した結果生じた現象であると推察している.

Fig.6には，よこ軸に椅子からの立ち上がり動作試技から 得られた人体帯電圧をとり, たて軸に脱衣動作試技から得ら れた人体帯電圧をとり，各データをプロットした結果と相関 係数（r) を示した。 ○で示したデータは帯電防止加工作業 服から, ○は帯電防止未加工作業服から得られたデータであ る。なお，Fig.には椅子からの立ち上がり動作試技と脱衣動 作試技から得られた人体帯電圧との相関係数と回帰線を記入 した。両者間には相関係数 -0.86 の負の相関関係が認められ る. 試料数が 10 点であるため断言はできないが, 脱衣動作 試技と椅子からの立ち上がり動作試技から得られる人体带電 圧との間には逆極性で良好な関係性が成立している可能性が ある. 静電気带電現象は帯電量の絶対值が問題になるので, 考案した 2 種類の試技のいずれによっても作業服の静電気带 電性を人体帯電圧によって評価することが可能であるものと 考えている.

\section{4. 結 言}

人体帯電圧による作業服の静電気带電性を評価する目的な らびに市販の作業服から実際にどの程度の人体帯電圧が生じ るのかを確認する目的から 2 種類の試技を考案した，試技は， 
作業服を着用した実験者が静止起立状態で作業服とインナー ウエアを一定の速度で一定時間摩擦し, 素早く脱衣する試技 （脱衣動作試技）および汎用的な事務椅子に作業服を着用し た実験者が座り，作業服の背部と椅子の背もたれ部分を一定 の角度で一定の速度で一定時間摩擦し, 直ちに急速に立ち上 がる試技（椅子からの立ち上がり動作試技）の2 通りである. 実験には上下一対の市販の帯電防止未加工作業服 4 点ならび に帯電防止加工作業服 6 点の合計 10 点の試料作業服を選定 した.

脱衣動作試技においては試料作業服を脱いだ瞬間に人体帯 電圧の急激な上昇が認められ，椅子からの立ち上がり動作試 技においては立ち上がり動作を行うと瞬時に人体帯電圧は急 激に上昇し, 相当の人体帯電圧が検出されることがわかった. また，椅子からの立ち上がり動作試技から得られる人体帯電 圧は脱衣動作試技から得られる人体帯電圧よりも高いことが 確認された。脱衣動作試技においてはすべての帯電防止作業 服が $3 \mathrm{kV}$ 未満の範囲内に収まっており, JIS 規格適合作業服 および IEC 規格適合作業服を着用すれば，脱衣のような通常 の動作であれば, 静電気的な危険性は低く, 制電加工効果は 認められることが確認された。しかし，椅子からの立ち上が り動作試技により生じる人体帯電圧からは帯電防止加工作業 服であっても 6 点中 5 点が $3 \mathrm{kV}$ 以上の人体帯電圧を示し, そ のうちの 4 点から $5 \mathrm{kV}$ 以上の人体带電圧が検出された。帯電 防止作業服の $2 / 3$ が静電気による火花放電の危険が懸念され るレベルにあることがわかった。 したがって, 帯電防止作業 服を着用していても激しい摩擦をともなうような動作や作業 の後に, 急速に立ち上がるような動作は静電気災害発生の原 因となり得る所作であるものと考えられた。

なお，試料作業服の表面電気抵抗率と 2 種類の試技から得
られた人体帯電圧の関係を検討した結果，両者間には明確な 関連性は認められなかった。

\section{謝 辞}

本研究は JSPS 科学研究費助成事業 (学術研究助成基金助 成金）課題番号 $15 \mathrm{~K} 00750$ の助成を受けて実施したものであ る。ここに，謝意を表する。

\section{References}

[1] Nambata M, Yoshida T (2016) Journal of the Institute of Electrostatics Japan, 40, 295-301

[2] Ishida T (2017) Journal of the Institute of Electrostatics Japan, 41, 169-172

[3] Yamaguma M (2012) Journal of the Institute of Electrostatics Japan, 36, 116-121

[4] Kodama T, Yamaguma M (2012) Journal of the Institute of Electrostatics Japan, 36, 122-127

[5] Yanagida K (2012) Journal of the Institute of Electrostatics Japan, 36, 128-132

[6] Choi K S, Mogami T (2012) Journal of the Institute of Electrostatics Japan, 36, 133-137

[7] Mainichi Shinbun (in Japanese) (2006) 2006.01.18, 1,23

[8] JIS T 8118 (2001)

[9] IEC 61340-5-1 (2016)

[10] Pailthorpe M T (1988) Textile Research Journal, 58, 335-337

[11] Kimura H, Matsuoka T, Kanai H, Morishima M, Hasegawa M (2011) Journal of the Institute of Electrostatics Japan, 35, $183-188$ 